\title{
Rare occurrence of coexistent squamous cell carcinoma and basal cell carcinoma in a case of Xeroderma Pigmentosum
}

\section{Kseroderma Pigmentosum ile birlikte görülen Skuamöz Hücre Karsinomu ve Bazal Hücre Karsinomu: Nadir bir vaka sunumu}

\author{
Suguna B.V ${ }^{1}$, Aparna Muralidhar ${ }^{2}$, Hemalata M ${ }^{1}$, Sadaf Ahmad ${ }^{3}$
}

\begin{abstract}
Xeroderma Pigmentosum is an inherited disorder of DNA repair characterised by defective nucleotide excision repair, which is involved in repairing ultraviolet rays induced cross linking of pyramidine residues. Affected individuals are at increased risk of development of mucocutaneous cancers at a much earlier age than normal. This genodermatosis affects both sexes and all races. The incidence in India is still unknown. We report one such case of a nine year old boy with co-existent squamous cell carcinoma and basal cell carcinoma of the face.
\end{abstract}

Key words: Xeroderma Pigmentosum, DNA repair, ultraviolet rays.

Öz

Kseroderma Pigmentosum, ultraviyole ışın kaynaklı piramidin kalıntılarının çapraz bağlanmasının tamirinde rol oynayan nükleotid eksizyon tamiri aşamasındaki defekt ile karakterize kalıtsal bir DNA onarım bozukluğudur. Etkilenen bireyler normalden çok daha erken yaşta mukokutanöz kanser gelişme riski altındadır. Bu genodermatoza, tüm ırklarda ve her iki cinsiyette rastlamak mümkündür. Xeroderma Pigmentosum'un Hindistan'da görülme sıklığı hala bilinmemektedir. Bu çalışmada dokuz yaşında erkek hasta birlikte skuamöz hücreli karsinom ve yüz bazal hücreli karsinomu olan bir olguyu sunduk.

Anahtar kelimeler: Xeroderma Pigmentosum, DNA onarımı, ultraviyole ışınları

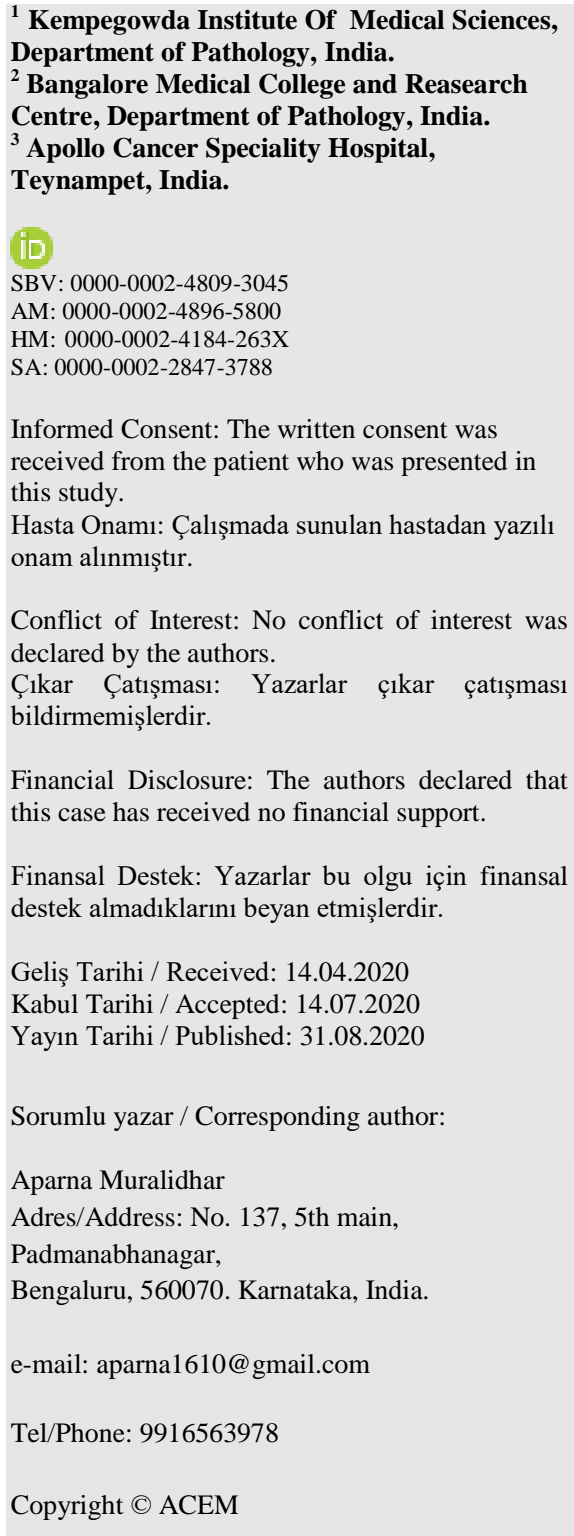




\section{Introduction}

Xeroderma Pigmentosum is a rare, autosomal recessive genodermatosis characterized by deficient DNA repair. It involves both sexes and all races with an incidence of 1:2,50,000 and a gene frequency of 1:200. A high incidence of consanguinity between parents has been noted. There is genetic heterogeneity with at least nine different groups recognized by somatic cell fusion studies - so-called 'complementation groups'. These include types A-G and Xeroderma Pigmentosum variant.

Clinically, it is characterised by photophobia, severe solar sensitivity, cutaneous pigmentary changes, xerosis and early development of mucocutaneous and ocular cancers, particularly in sun exposed areas. Neurological abnormalities are present in up to $20 \%$ cases.[1]

We present a rare case of co-existent squamous cell carcinoma and basal cell carcinoma in a boy with Xeroderma Pigmentosum.

\section{Case report}

A nine year old boy presented to the dermatology department of our hospital with complaints of photosensitivity, reduced visual acuity and pigmentation on sun exposed areas of the body since one year. He had a nodular growth on the dorsum of nose since three months. The child was born to a first degree consanguineous marriage. The parents were clinically normal.

Clinical examination revealed an ulceroproliferative growth on the dorsum of the nose measuring $1.2 \times 0.8 \times 0.3 \mathrm{~cm}$. A pigmented macule measuring $0.3 \times 0.2 \mathrm{~cm}$ was noted in the left preauricular region. Variably sized pigmented macules were seen on the sun exposed regions (Figure 1).

The histopathology of lesion from the dorsum of the nose showed an infiltrating malignant neoplasm with islands and nests of polygonal tumor cells with moderate eosinophilic cytoplasm, vesicular to hyperchromatic nuclei with prominent nucleoli and keratin pearls. A diagnosis of well differentiated squamous cell carcinoma (SCC) was made (Figure 2).

Biopsy from the lesion in the preauricular region showed nests of basaloid cells with peripheral palisading and clefting at the tumor - stroma interface; suggestive of basal cell carcinoma (BCC) (Figure 3).

Based on the above presentation, a clinical diagnosis of Xeroderma Pigmentosum was made. The patient was referred to an appropriate oncology centre for further management.

The patient's consent was obtained for this case study.

\section{Discussion}

Xeroderma Pigmentosum was first reported in 1874 by dermatologist Moriz Kaposi.[2] The term 'xeroderma pigmentosum', means pigmented dry skin. It occurs with a frequency of approximately 1 in 250000 in Europe and the USA . In Japan, the frequency has been reported to be higher ( 1 in 40 000).[3]

Its incidence in India is not known. However, many cases have been reported from South India, especially Karnataka.[4] The disease has a marked hereditary tendency and is transmitted as an autosomal recessive disorder. It is frequent following consanguineous marriage.

Xeroderma Pigmentosum is characterised by mutation in genes involved in nucleotide excision repair. Mutations in DNA-repair genes themselves are not oncogenic, but their abnormalities greatly enhance the occurrence of mutations in other genes during the process of normal cell division. [5]
Figure 1- Clinical photograph showing growth on dorsum of nose and pigmented macules on sun exposed regions of the body.

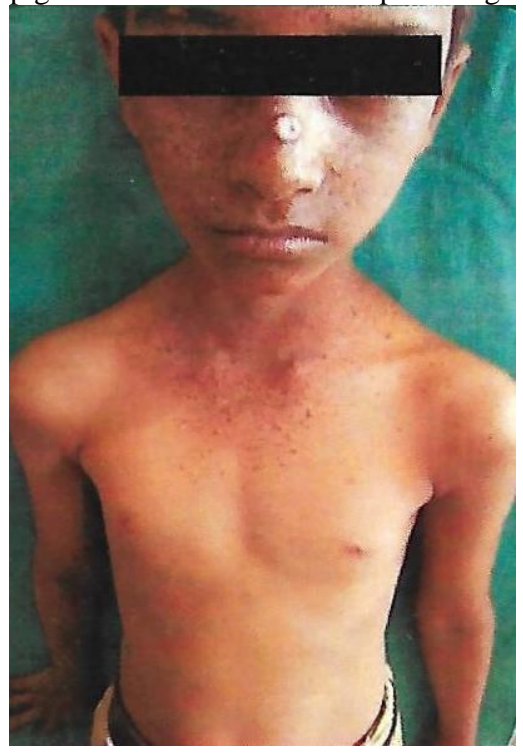

Figure 2 - Photomicrograph of squamous cell carcinoma, H\&E, 100x. Arrow shows a keratin pearl.

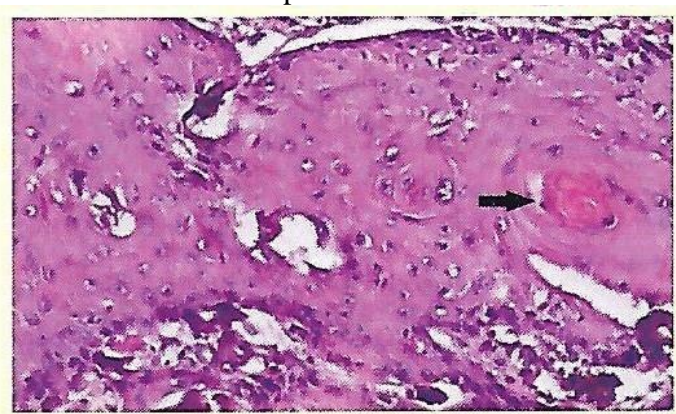

Figure 3 - Photomicrograph of basal cell carcinoma, H\&E, 100x. Inset $\mathrm{H} \& \mathrm{E}, 400 \mathrm{x}$.

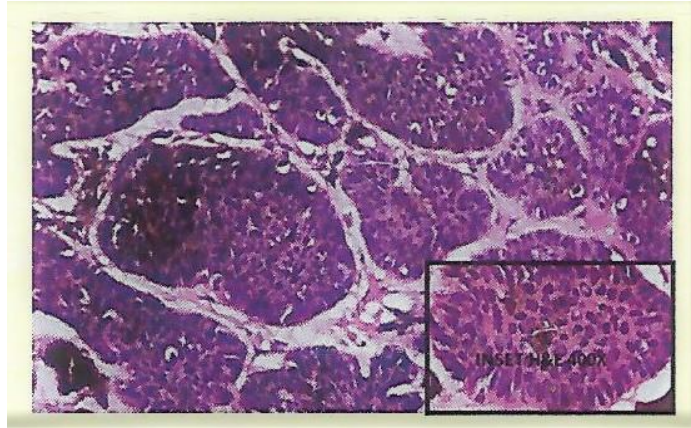

A review by DiGiovanna et al.[6] summarised the process of ultraviolet radiation induced DNA damage, according to which exposure of DNA to ultraviolet radiation produces multiple nucleic acid based photoproducts. These serve as substrates for DNA repair via the nucleotide excision repair. The damaged DNA is recognized by the transcription-coupled repair (TCR) pathway and global genome repair (GGR) pathway. Mutations in any of these proteins from either the TCR, GGR or nucleotide excision repair pathways lead to abnormalities in DNA repair.[2]

The earliest changes usually develop before the age of 2 years with a severe sunburn reaction. There is development of multiple freckles with variable melanin pigmentation and interspersed hypopigmented macules. Later, dry, scaly skin (xerosis) with poikilodermatous features are seen. Solar keratoses, cutaneous horns, keratoacanthomas, squamous and basal cell carcinomas, atypical fibroxanthoma, malignant melanomas and angiomas, may develop in late childhood.[1] 
The first malignant tumours may develop as early as third or fourth year of life, with a median age of onset of eight years.

Patients also experience a variety of ophthalmologic and central nervous system involvement as well. Neurodegeneration occurs in about $24 \%$ patients.[2]

Among the cutaneous malignancies, basal cell carcinoma, squamous cell carcinoma and melanomas are common.[3]

A similar case of squamous and basal cell carcinomas in the face in a 14 year old male has been reported in Maharashtra.[7] However, our patient presented much earlier. Halkud et al [8] reported 11 cases of Xeroderma Pigmentosum, of which most had facial SCC and BCC by $8-9$ years of age, similar to our study.

Prophylactic measures such as avoidance of sunlight, minimizing ultraviolet rays exposure with the use of protective clothing, application of sunscreens, sunglasses with side shield play a significant role. Early and adequate excision of all tumors is essential to reduce the morbidity to a certain level. Chemoprohylaxis with systemic retinoids, topical T4 endonuclease V, 5 Fluorouracil and imiquimod significantly reduce the rate of new cutaneous malignancies in Xeroderma Pigmentosum. [9,10,11] Dermabrasion is another effective modality, as reported by König A et al. [12]

Awareness about this rare condition and prevention of ultraviolet rays induced skin damage should be propagated. Genetic counselling with emphasis on implications of consanguineous marriage plays a key role in its prevention. As the incidence of Xeroderma Pigmentosum in India is still unknown, [13] reporting every case may help in determining the incidence and prevalence of this genodermatosis in our country.

\section{References}

1. Weedon D.Weedon's skin pathology.3rd ed. Churchill Livingstone Elsevier.Philadelphia.2010:p.274-76.

2. Black JO. Xeroderma Pigmentosum. Head Neck Pathol. 2016;10(2):139-144. doi:10.1007/s12105-016-0707-8.

3. Irvine AD, Mellerio JE. In: Burns T, Breathnach S, Cox N,Griffiths $C$ (editors).Rook's Textbook of Dermatology. 8th ed.Wiley Blackwell.West Sussex,UK.2010:p.15.70-15.74.

4. Tamhankar PM, Iyer SV, Ravindran S, Gupta N, Kabra M, Nayak C, et al. Clinical profile and mutation analysis of xeroderma pigmentosum in Indian patients. Indian J Dermatol Venereol Leprol 2015;81:16-22.

5. Kumar V, Abbas AK, Aster JC. Robbins and Cotran Pathologic Basis of Disease.9th ed.Elsevier Saunders. Philadelphia.2015:p.314-15.

6. DiGiovanna JJ, Kraemer KH. Shining a light on xeroderma pigmentosum. J Invest Dermatol. 2012;132:785-96.

7. Prabhu VV, Kale S, More S. Xeroderma pigmentosum: Composite cutaneous malignancies A nightmare. Indian J Paediatr Dermatol 2015; $16: 142-5$

8. Halkud R, Shenoy AM, Naik SM, Chavan P, Sidappa KT, Biswas S. Xeroderma pigmentosum: clinicopathological review of the multiple oculocutaneous malignancies and complications. Indian J Surg Oncol. 2014;5(2):120-124.

9. DiGiavanna JJ.Retinoid chemoprevention in patients at high risk for skin cancer. Med Pediatr Oncol.2001 36:564-567

10. Yarosh D, Klein J, O’Connor A, Hawk J, Rafal E, Wolf P (2001) Effect of topically applied $\mathrm{T} 4$ endonuclease $\mathrm{V}$ in liposomes on skin cancer in xeroderma pigmentosum: a randomized study. Xeroderma pigmentosum study group. Lancet 357:926-929.

11. Lambert, W.C. and Lambert, M.W. Development of Effective Skin Cancer Treatment and Prevention in Xeroderma Pigmentosum. Photochem Photobiol,2015; 91: 475-483. doi:10.1111/php.12385

12. König A, Friederich HC, Hoffmann R, Happle R. Dermabrasion for the Treatment of Xeroderma Pigmentosum. Arch Dermatol. 1998;134(2):241-242.

13. Chaudhary M, Jajoo SN, Agarwal R (2012) Xeroderma Pigmentosum: A Case Report of Two Siblings. J Immunodefic Disor 1:2. 